\title{
Generational dynamics in agriculture: reflections on rural youth and farming futures
}

\section{Ben White}

Emeritus Professor of Rural Sociology International Institute of Social Studies Kortenaerkade 12

2518 AX The Hague

The Netherlands

<white@iss.nl>

\begin{abstract}
This short article reflects on the articles on rural youth in the Maghreb collected in this volume. It first offers some general remarks on the importance of a research and policy focus on the problem of generational succession in agriculture, then some comparative observations from recent research in Indonesia that provides some contrast with the North African cases, and finally some ideas about relevant frameworks and questions for future comparative research.
\end{abstract}

Key words: agriculture; generation; Indonesia; research; rural youth.

Subjects: territory, land use, agricultural and food production policy; tools and methods.

\section{Résumé}

Dynamiques générationnelles dans le domaine agricole : réflexions sur les jeunes ruraux et l'avenir de l'agriculture

Cet article propose une réflexion sur les articles sur les jeunes ruraux au Maghreb contenus dans ce numéro spécial. Il présente d'abord quelques remarques générales sur l'importance d'une politique et d'une recherche mettant l'accent sur le problème du renouvellement des générations en agriculture. Ensuite, il élabore quelques observations comparatives à partir d'études récentes en Indonésie qui contrastent avec les études de cas du Maghreb. Enfin, il propose quelques idées de cadres d'analyse et de questions pour des recherches comparatives sur le sujet.

Mots clés : agriculture ; génération ; Indonésie ; jeunes ruraux ; recherche.

Thèmes : méthodes et outils; territoire, foncier, politique agricole et alimentaire.

\section{Agriculture and the problem of generations}

It has been a pleasure to read this path-breaking collection of studies on rural youth and farming in the Maghreb. My short reflections are in three parts. This first section considers the importance of a research and policy focus on the problem of generations in agriculture. The second section provides a few comparative observations from recent research in Indonesia, and the final section suggests some directions for future comparative research.

The world's agriculture faces a looming problem of generational succession, which until recently has gone largely unnoticed in both research and policy discourse. In most countries, the farming population is ageing and
Reprints: B. White

To cite this article: White B, 2015. Generational dynamics in agriculture: reflections on rural youth and farming futures. Cah Agric 24: 330-334. doi : 10.1684/agr.2015.0787 
in many countries large numbers of farmers appear to have no successor; even though rural youth unemployment rates are high, it is widely claimed that young people are not interested in farming (Proctor and Lucchesi, 2012). Meanwhile, the rapid rise in farm land prices makes farm land an attractive target for corporate investment and large-scale industrial farming, at the same time as it puts land beyond the reach of young people who would like to make a start in farming.

Who are these young rural people? In most rural areas of the world, the new generation of young men and women has grown up with more formal education than their parents had. At the same time, 'youth' itself has become prolonged (compared to previous generations) as young people stay longer in school or college, marry later and (willingly or unwillingly) postpone entry into the labour force. As education spreads, the civil service or other professional careers which young educated people used to aim for are increasingly an unrealistic target, leading sometimes to doubts about 'where does the rural educated person fit?' (Morarji, 2010), or to 'boredom and despair' (Schielke, 2008), but also sometimes to more creative responses, both in rural areas (White, 2012; Berckmoes and White, 2014) and among those who have migrated to the cities during this period of 'waithood' (Honwana, 2012).

Thinking about young people and farming raises fundamental questions about the future, both of rural young women and men, and of agriculture itself. Agriculture stands at a crossroad between:

- further size and scale enlargement, more industrial farming under corporate ownership (and further decline in the number of livelihoods supported by agriculture);

- farm size maintenance or even reduction, labour-driven intensification on smallholder 'family farms', providing more livelihoods, better products, and more sustainable modes of producing on the land (as recommended by IAASTD, 2009).

By 'family farming' and 'smallholder farming' here we refer not so much to the size (acreage) of the farm unit, but to the manner and 'scale' of its operation (for this distinction see van der Ploeg, 2013), where owners or tenants themselves manage and work on the farm, often with the help of family members but not ruling out the use of hired workers.

If sustainable agricultural futures are to be realised, and if young people are going to have a place in those futures, the problems that young people face in establishing themselves as farmers have to be taken seriously and given much more attention than has been the case in recent policy debate, and in recent research. For these reasons, it is important for research to go beyond the more common focus on why young people choose to leave farming, and explore young people's pathways into farming by documenting the experiences of young men and women who are establishing themselves as farmers (or are trying to do so). This is why it has been so rewarding to read the collection of studies in this volume. They show a young generation of rural men who are relatively well-educated, eager to obtain farm land and to practise innovative and creative farming on it, in different ways than their fathers did. Some (not all) of the studies also focus on young rural women and the gender norms that prevent them from becoming farmers in their own right, even though some of these women work on the farms of male relatives. All of the studies show young people's energy, dynamism and creativity in creating room for manoeuvre within the spaces and constraints of patriarchal rural society which constrain both young men's and women's aspirations in different ways.

The problem of generational renewal in agriculture is finally getting some attention internationally. Recent policy reports (IFAD, 2010 and 2011; Sumberg et al., 2012; FAO, 2014) give special attention to rural youth and provide examples of efforts to facilitate young people's access to land in various countries. An important but littleknown report Girls grow: a vital force in rural economies (Chicago Council, 2011) underlines the importance of viewing girls and young women as future farmers and major stakeholders in agriculture and natural resource management in their own right. All these reports recognise that young men and women are the key to innovation, energy and creativity in developing new, environmentally responsible and highly productive farming practices.
Intergenerational tensions and conflicts on the transfer of agrarian resources have been a recurring theme in studies of agrarian change, especially in sub-Saharan Africa (Quan, 2007; Amanor, 2010; Kouamé, 2010; Sumberg et al., 2012; Berckmoes and White, 2014; Temudo and Abrantes, 2015); studies like these can inspire us to turn a similar lens on other parts of the world, where these dimensions of rural life have so far been largely neglected.

I hope and expect that in the coming years we will see much more research of this kind, in other countries. Besides generating comparative information, studies of this kind can make both theoretical and methodological innovations and contributions to policy debates on agricultural futures, rural youth employment problems and the generational reproduction of farming communities. By concentrating on young people who are (trying to become) farmers, we can explore young men and women's agency in overcoming barriers and realising aspirations. Young people are the most important potential source of innovation, energy and creativity in developing new, environmentally responsible and highly productive farming practices. Much can be done in general education, the public media and particularly social media to correct the prevailing images of farming and rural life. Concrete examples of young men and women farmers, practising new, smart and creative ways of production and making a decent living out of it, can potentially have powerful impact.

\section{Young people and farming in Indonesia}

Recently, the Indonesian research centre, Akatiga, completed a study on the aspirations of young people and their attitudes to possible farming futures in Indonesia's rice producing regions, as part of a larger study on local problems of food security and self-sufficiency. In the 12 villages studied, we did not find examples of the new generation of entrepreneurial, innovative young farmers, which are seen in the North African studies (which does not mean they do not 
exist, in other parts of Indonesia or in other agricultural sub-sectors such as vegetable, fruit, livestock and poultry farming). The following summary is drawn from an Indonesian-language report currently in press (Nugroho and Herawati, 2015); a short, semi-popular English-language version is also available (Akatiga and White, 2015).

In most villages, landlessness is widespread and less than half of farmers own the land they cultivate. Inequalities in landholding mean that most young people have no realistic prospect of becoming farmers, or at least not while they are still young. The only people who have a possibility of getting some land while they are still young are those who come from the few wealthy land-owning households in each village, whose parents could afford to release part of their land. But these privileged young people typically go to university or some other form of tertiary education and aim for a future in a secure, salaried job; their parents also have the resources to get them into these jobs. They may look forward to inheriting and owning land, but as a source of income through rent; they have no interest in farming it.

For the larger numbers of young people growing up in smallholder farming families, their parents have too little land to hand over a part of it while they are still young. Children may eventually inherit some land, but will have to wait may be until their 40 s or 50 s when they finally receive land from their parents. Meanwhile, for the many young people whose parents are landless, there is only the prospect of becoming a sharecropper or farm labourer, unless they can find another way to access land. For these young people the only possible way to become a farmer is to find work first outside agriculture (and often outside the village), hoping to save enough money to buy or rent some land.

But buying land has become an increasingly unrealistic option except for those who are already rich, due to speculative investment in land (by nonfarmers, both rural and urban, private and corporate) and rising land prices. With local wages or informal sector earnings not much more than US \$ 100 per month, and migrant worker wages in factories, or in oil palm plantations in Malaysia around \$250, even if a young person could save half of those earnings, it would take him or her many years (in the expensive locations, 100 years) to buy a tiny rice farm of only 0.4 ha.

It's not surprising, then, that so many young rural men and women decide to migrate, to various kinds of paid jobs or informal-sector work, sometimes in other regions or as far away as Malaysia. But young people's decisions to farm or not to farm, and to stay in the village or to migrate, are not permanent, lifetime decisions. Many of today's older farmers themselves migrated when young, and returned when they had saved money or when land became available.

There may of course be other reasons why leaving the village seems attractive to young people. The rural world and farmers are depicted in media (TV, schoolbooks, etc.) as backward and poor, and patriarchal control is sometimes strong. But many dimensions of rural life are changing fast. In many villages connectivity is now as good as in the cities, motorbikes are cheap and common and all young people are busy with Facebook accounts. In the Javanese village of Kali Loro, for example - which I first studied in 1972 when there was no telephone, TV or electricity in the village - nowadays many children have their own cell phones before leaving primary school. Those whose parents cannot afford them may be helped by an elder sibling or cousin who has found work outside the village, and those without phones can still open Facebook accounts and borrow their friends' phones. These young people engage actively with global ideas and global youth lifestyles, which may make them look at rural life and farming in different ways than their parents did. But for most of the young people we have talked to, it is not rural life or agriculture as such that makes them decide to move away, but the lack of local jobs and the poor incomes from smallholder farming in its current state, after some decades of government neglect.

This case, then, is rather different from most of the cases from the Maghreb reported in this collection. At least in the main rice-growing regions of Indonesia we do not see young people moving into farming and eager to develop new and creative farming styles. But studies like this also suggest that we need to take a longer-term, life- course perspective when we look at young people's migration and their apparent decision not to become farmers. If the world's food needs are to be met in future largely by smallholder farmers, rather than by the large corporate industrial food estates favoured by the technocrats, rural life and farming have to be made more attractive to young people. While men and women formally have equal rights to own land, there are many practical gender distinctions and barriers to young women's access to land and farming opportunities. We need to have a clear idea of the main barriers - both practical and cultural - to young people's entry into farming, either while still young, or as a later lifetime option. The issue of young people and access to land needs to be taken seriously; the whole broader issue of intergenerational transfer of agrarian resources (including land, but also knowledge and decisionmaking power) has attracted little attention in research and policy. Further comparative work is clearly needed here. In the next section which reflects on future research directions, I am drawing on a proposal for comparative research on 'Becoming a young farmer' which I have recently developed together with collaborators in Canada, China, India, Indonesia, and the Netherlands.

\section{Notes on future research directions}

Comparative research on these issues, clearly, has to combine perspectives and frameworks from agrarian studies and youth studies. It should focus both on the barriers which young rural men and women confront in accessing land, knowledge and other resources, and the role of policies, institutions and young people's own efforts in overcoming these barriers. It should mainstream gender distinctions and also differences between 'continuer' and 'newcomer' young farmers. It should also enhance our understanding of the role of young farmers, in adopting and developing innovative and sustainable farming practices. Agrarian studies helps us to better understand the structure of rural 
societies in the selected countries and regions, the possible future trajectories of the agri-food sector and in particular the underlying and continuing debate on large versus small-scale agricultural futures. Agrarian political economy allows us to depict and compare agrarian structures by investigating the social relations and dynamics of production and reproduction, property and power in agrarian formations and their processes of change, both historical and contemporary' (Bernstein, 2010). This broad structural perspective, together with a closer focus on the particular characteristics of smallholder farming (van der Ploeg, 2013), can provide the basic analytical tools for this aspect of the research.

A youth studies perspective, focusing on the generational dimensions of the social reproduction of rural communities, helps us to understand the lives of young people, their position in the agrarian structures just mentioned and their paradoxical (apparent) turn away from farming in this era of mass rural unemployment and underemployment. It also provides an important reminder of the need and the right of young people to be properly researched - not as objects, but as subjects and where possible as participants in research. Key concepts which we can draw from the 'new' youth studies are the ideas of youth as actors in social and economic renewal, youth as identity, and youth as generation (Jones, 2009). These ideas reflect the importance of a relational approach to studying young people's experiences with farming, the dynamics of relations between younger and older generations, and the role of these dynamics in the social reproduction of agrarian communities (Archambault, 2014; Berckmoes and White, 2014). At the same time, young people are not homogeneous; generation must be seen as 'intersecting' with other important social categories such as socialeconomic class and gender (Wyn and White, 1997; Jones, 2009). As already noted, research should incorporate a systematic focus on young female (would-be) farmers. Traditional agrarian societies are typically sites of patriarchy in both gender and generational relations - 'patriarchy' in its original sense, as power of male over female, and of old over young reflected in patterns of harsh discipline, and cultural emphasis on respect for the older generation, commonly seen historically in peasant societies worldwide (Stearns, 2006). Young people however, are not passive victims within these patriarchal structures, but exercise a "constrained agency" (as we have seen in the various studies from the Maghreb).

Bringing these two perspectives together will help us to understand the intergenerational tensions that we see almost everywhere in rural communities, particularly young people's problems in getting access to farmland and other agriculture-related opportunities in societies where gerontocracy, agrarian inequality and corporate penetration of the agri-food sector, in varying degrees, are the order of the day.

Another possibly key distinction to be explored is that between 'continuers' (those who take over their parents' farm) and 'newcomers'. In a recent study of young farmers in Spain and Canada (Monllor and Fuller, 2012), the finding that more than half of the young farmers were, in fact, 'newcomers underlines the need to go beyond a narrow focus on the children of existing farmers. There is a strong supposition - but one on which we should keep an open mind, as the North African studies demonstrate that 'newcomer' farmers are likely to be more critical of mainstream farming practices and the most important innovators.

The kinds of questions that I think are important in comparative research are briefly summarised below.

\section{Agrarian context}

What are the general patterns and trends of farmland ownership and access, farm sizes and labour use? How have farmland prices changed (in relation to general price movements)? What are the trends in age structure of the farming population? What are the typical modes of transfer of farmland and property between generations? How are resources divided among sons and daughters?

\section{Becoming a young farmer}

How do young people become farmers? What are the resources they need and access in the process? How do they access land and credit? What challenges do they encounter and how do they deal with them? How do they acquire and develop farming knowledge and skills? What kind of social networks do they rely on and what kind of support do they get from these networks? How do young women farmers fare? How do they deal with social, economic and other barriers to becoming farmers in their own right?

\section{Young farmers and innovation}

What are young farmers' attitudes to conventional farming practices? Are young farmers in general and newcomers in particular, more flexible and innovative with regard to farming compared to older farmers and continuers? What role do relatively new technologies such as mobile phones, the Internet and social media play in the innovation process and dissemination?

\section{Young farmers in policy and agenda-setting}

How do agrarian and rural policies affect young people in farming? What policies make it more or less easy for young people to get into farming? What specific kinds of support are available for young farmers? How do young people attempt to influence the level and contents of such support? Are young farmers organised? How are they involved in existing farmer unions, associations and/or political parties, and/or in dedicated young-farmer organisations, and new modes of networking among young farmers (with particular attention here to social media)? How do they go about influencing political parties and policy makers, and with what degree of success?

\section{References}

Akatiga, White B, 2015. Would I like to be a farmer? Inside Indonesia 120. www.insideindonesia.org

Amanor KS, 2010. Family values, land sales and agricultural commodification in South-Eastern Ghana. Africa 80:104-25.

Archambault C, 2014. Young perspectives on pastoral rangeland privatization: intimate exclusions at the intersection of youth identities. 
European Journal of Development Research 26:204-18.

Berckmoes L, White B, 2014. Youth, farming and precarity in rural Burundi. European Journal of Development Research 26:190-203.

Bernstein H, 2010. Class analysis of agrarian change. Agrarian change and peasant studies series. Halifax: Fernwood Press.

Chicago Council, 2011. Girls grow: a vital force in rural economies. Chicago: The Chicago Council on Global Affairs.

FAO, 2014. Youth and agriculture: key challenges and concrete solutions. Rome: FAO with IFAD and CTA.

Honwana A, 2012. The time of youth: work, social change and politics in Africa. Boulder, Co: Kumarian Press.

IAASTD, 2009. Synthesis report: agriculture at a crossroads. International assessment of agricul tural science and technology for development. Washington: Island Press.

IFAD, 2010. Rural Poverty Report 2011. Rome: International Fund for Agricultural Development.

IFAD, 2011. Feeding future generations: young rural people today, prosperous farmers tomorrow.
Proceedings of the Governing Council High-Level Panel, November 2011. Rome: International Fund for Agricultural Development.

Jones G, 2009. Youth. Cambridge: Polity Press.

Kouamé G, 2010. Intra-family and socio-political dimensions of land markets and land conflicts: the case of the Abure, Côte d'lvoire. Africa: The Journal of the International African Institute 80:126-46.

Monllor N, Fuller A, 2012. Farm entry: a comparative analysis of young farmers, their pathways, attitudes and practices in Ontario (Canada) and Catalunya (Spain). 2012. http://www.laccb.cat/ fitxer/2283/Monllor Farm Entry Report 2012.pdf

Morarji K, 2010. Where does the rural educated person fit? Development and social reproduction in contemporary India. In: McMichael P, ed. Contesting development: critical struggles for social change. London: Routledge.

Nugroho Y, Herawati R, 2015. Menguak realitas orang muda sektor pertanian dim perdesaan. Jurnal Analisis Sosial. (In press).

Proctor F, Lucchesi V, 2012. Smallscale farming and youth in an era of rapid change. London: IIED. http://pubs.iied.org
Quan J, 2007. Changes in intra-family land relations. In: Cotula L, ed. Changes in 'customary' land tenure systems in Africa. London: International Institute for Environment and Development.

Schielke S, 2008. Boredom and despair in rural Egypt. Contemporary Islam 2:251-70.

Stearns P, 2006. Childhood in world history. London: Routledge.

Sumberg J, Akua Anyidoho N, Leavy J, te Lintelo D, Wellard K, 2012. Introduction: the young people and agriculture 'problem' in Africa. IDS Bulletin 43:1-8

Temudo M, Abrantes M, 2015. The pen and the plough: Balanta young men in Guinea-Bissau. Development and Change 46:464-85.

van der Ploeg JD, 2013. Peasants and the art of farming: a Chayanovian manifesto. Halifax and Winnipeg: Fernwood Publishing.

White B, 2012. Agriculture and the generation problem: rural youth, employment and the future of farming. IDS Bulletin 43:9-19.

Wyn J, White R, 1997. Rethinking Youth. London: Sage Publications. 